\title{
The influence of clove leave extract (Syzygium aromaticum) on growth performance and bacterial population of broiler chickens raised in stressful conditions of high stocking density
}

\author{
Nur Sjafani $^{\mathrm{a} *}$ (D) Said Hasan ${ }^{b}$ | Yusri Sapsuha ${ }^{\text {iD }}$ \\ Animal Husbandry Program, Faculty of Agriculture, Universitas Khairun, Ternate, North Maluku, Indonesia. \\ Department of Biology, Faculty of Teacher Training and Education, Universitas Khairun, Ternate, North Maluku, Indonesia.
}

\begin{abstract}
Broilers maintenance at high stocking density impacts uncomfortable conditions; this increases the potential for stress, reduces feed consumption, and reduces production performance and health in broiler chickens. This study aims to evaluate the effect of clove leaf extract on growth performance and microbial population in the digestive tract of broiler chickens reared at high density. From the eighth day, five treatment groups, T0 (negative control with a typical density of $10 \mathrm{birds} / \mathrm{m}^{2}$ ), T1 (positive control with a high density of $16 \mathrm{birds} / \mathrm{m}^{2}$ ), T2, T3, and T4 with a high density of 16 birds $/ \mathrm{m}^{2}$, were randomly assigned from 444 broilers (bodyweight of $129.78 \pm 0.75 \mathrm{~g}$ ) with six repetitions each on the eighth day. The feed includes clove leave extract as much as $0.5,0.75$, and $1 \mathrm{ml} / \mathrm{kg}$ for T2, T3, and T4, respectively. The weight gain, feed intake, and feed conversion ratio were tracked weekly. One chicken from each replicate was taken randomly, slaughtered, and feathered on day 35. The digesta was taken from the ileum and cecum to measure the intestinal bacterial population and put into a sterile container. Digesta from the duodenum, jejunum, ileum, and cecum were also collected to determine $\mathrm{pH}$ levels. MRS agar was used to determine the amount of LAB in the digesta. The findings revealed that giving clove leaf extract of feed to broiler chickens kept at high stocking density could higher body weight gain $(P<0.05)$, higher feed consumption $(P<0.05)$, decreased the $\mathrm{pH}$ of the ileum and cecum $(P<0.05)$, increased lactic acid bacteria and decreased coliform bacteria in the ileum and cecum $(P<0.05)$.
\end{abstract}

Keywords: bacterial population, broiler, clove leaf, performance, weight gain

\section{Introduction}

Broiler chickens maintenance at high stocking density is carried out with the aim of increasing meat production while maximizing profits. An increased high stocking density has an impact on uncomfortable conditions, in addition to production efficiency. This increases the potential for stress, reduces feed consumption, and reduces production performance and health in broiler chickens. In addition, Dozier et al (2006) study found that stress due to maintenance at high stocking densities negatively influences the balance of microbes in the intestine by reducing beneficial bacteria and increasing pathogens, leading to the decreased growth performance of chickens.

Farmers routinely utilize antibiotic growth promoters (AGP) to increase feed utility (by chickens) and the health performance of broiler chickens. In terms of rearing broilers at high densities, AGP has been shown to boost growth, prevent pathogenic bacterial infections, and increase feed conversion (Simitzis et al 2012; Guardia et al 2011). A recent study showed that the use of AGP could reduce the stress response in broilers due to its high density (Jeong et al 2020). However, AGP has been banned for use in rations in Indonesia since 2018. This is because AGP has been known to cause severe problems for consumers and cause residues in chicken products, so it is detrimental to human health (Suggiharto et al 2017). Based on these conditions, the poultry industry is anticipated to stop using AGP in broiler chickens and look for alternate ways to boost livestock development and chicken health. One of the efforts is by using herbal extracts.

Herbal extracts inclusion in poultry feed is reported to increase body weight gain. The results of a recent study related to the use of herbal extracts in broilers reared at high density (Sapsuha et al 2021) reported that it could improve performance and does not have a detrimental effect on carcass properties. Clove (Syzygium aromaticum) is a native plant of Indonesia widely used as a kitchen spice. Clove is a tropical plant with a strong fragrance (with a distinctive aroma) (Bhowmik et al 2012) and has antioxidant, antimicrobial, analgesic, antiobesity, and hepatoprotective activities in biological systems (Bhowmik et al 2012; Sulieman 
et al 2007). Clove flower is the major output of the clove plant, which is used as a spice with economic worth, but clove leaves, particularly dried ones, are a waste product with little economic use despite their high quantity of bioactive compounds. (Adu et al 2020). There is currently very little research on clove leaf extract to boost the productivity of broilers grown at high stocking density. This study aimed to see how clove leaf extracts affected broiler chicken growth and bacterial population in the digestive tract when they were maintained at a high stocking density.

\section{Materials and Methods}

\subsection{Making clove leaf extract}

Clove leaves were collected in Ternate City, North Maluku Province, Indonesia, from clove plantations. Before use, clove leaves were washed, air-dried, and ground into flour. Maceration technique by soaking in $4 \mathrm{~L} 96 \%$ ethanol solution for $3 \times 24$ hours was used to extract $1 \mathrm{~kg}$ of clove leaf flour. Stirring was done twice during the immersion phase, once in the morning and the evening. The filtrate obtained from the immersion was then filtered and evaporated using a rotary evaporator to generate a clove leaf extract solution.

\subsection{Ethical approval}

All procedures performed in the studies involving animals followed the institution's ethical standards or practice at which the studies were conducted. The research protocol and animal management followed Directive 142/UN44.C4/PP/2021 on the Animal Ethics Committee Faculty of Agriculture, Universitas Khairun.

\subsection{In vivo Experiment}

From 0 to 7 days of age, 444 Lohmann broiler chickens (unsexed) were kept together. Five treatment groups, T0 (negative control with a typical density of $10 \mathrm{birds} / \mathrm{m}^{2}$ ), T1 (positive control with a high density of 16 birds $/ \mathrm{m}^{2}$ ), T2, T3, and T4 with a high density of 16 birds $/ \mathrm{m}^{2}$, were randomly assigned from these broiler chickens (weight $129.78 \pm 0.75 \mathrm{~g}$ ) on day 8 , and each treatment was repeated six times. The feed was administered in the form of mash (Table 1) and was divided into two categories (days 1-21): starter feed and finisher feed (days 22-35). Clove leaf extract was introduced to the feed starting on day 8 in amounts of 1,2 , and $3 \mathrm{ml} / \mathrm{kg}$ for $\mathrm{T} 2, \mathrm{~T} 3$, and $\mathrm{T} 4$, respectively, while the $\mathrm{T} 0$ and $\mathrm{T} 1$ treatment feed received no clove leaf extract. There are no enzymes, antibacterial, antifungal, or antiprotozoal qualities in the prepared feed. Until day 35 , the animals were fed and given water ad libitum. On day 4 through eye drops, day 18 through drinking water, and day 12 through drinking water, all chickens were vaccinated with the commercial Newcastle (ND) vaccine. The chickens were kept in a vented broiler cage with rice husks as litter during the raising period. During the day, the temperature of the henhouse was recorded at $29^{\circ} \mathrm{C}$ $-31{ }^{\circ} \mathrm{C}$, while the humidity was around $70-75 \%$. Meanwhile, the temperature at night is about $25^{\circ} \mathrm{C}-28^{\circ} \mathrm{C}$ with humidity between $85-90 \%$. The researchers kept track of weekly weight gain, feed consumption, and feed conversion ratio (FCR). On day 35, one chicken was chosen at random from each replicate, slaughtered, feathered, and the internal organs removed.

Table 1 Feed ingredients and nutrient composition of the research ration.

\begin{tabular}{lll}
\hline Items (\%, except that otherwise mentioned) & Starter (1-21) & Finisher (22-35) \\
\hline Yellow corn & 56.10 & 15.45 \\
Fine bran & 16.32 & 14.42 \\
Fish flour & 20.32 & 2.40 \\
Palm oil & 2.40 & 0.30 \\
DL-methionine & 0.30 & 0.46 \\
Bentonite & 1.10 & 1.42 \\
Limestone & 1.42 & 1.45 \\
MCP & 1.45 & 0.20 \\
Premix & 0.20 & 0.08 \\
Chlorine chlorite & 0.08 & 0.31 \\
NaCl & 0.31 & 3,126 \\
Nutrient content based on feed composition table: & & 19.17 \\
ME (kcal/kg) & 2,936 & 3.31 \\
Crude protein & 21.15 & 4.73 \\
Crude fiber & 3.21 & 3210.17 \\
Extract eter & 4.45 & 86.19 \\
Nutrient content based on laboratory analysis: & & 18.97 \\
ME (kcal/kg) & 3128.14 & 4.64 \\
Dry matter & 85.64 & 2.43 \\
Crude protein & 20.78 & 10.17 \\
Extract eter & 4.32 & 3.18 \\
Crude fiber & 9.64 & \\
Ash & & \\
\hline
\end{tabular}


To measure the population of intestinal bacteria, digesta was taken from the ileum and cecum and put into a sterile sample container. Digesta was also taken from the duodenum, jejunum, ileum, and cecum to determine $\mathrm{pH}$ levels (using an electronic $\mathrm{pH}$ meter; Thermo Fisher Scientific Inc.). After incubation (aerobic) at $38^{\circ} \mathrm{C}$ for 24 hours, coliform and lactose-negative populations in the gut were enumerated as red and colorless colonies on MacConkey agar. MRS agar was used to determine the lactic acid bacteria (LAB) quantity in the digesta.

\subsection{Data Analysis}

This study was carried out using a completely randomized design. The data were analyzed using ANOVA (SPSS version 16.0), and the Duncan test was used to see only if there was a significant treatment effect.

\section{Results and Discussion}

Performance data of broiler chickens treated with clove leaf extract are shown in Table 2. During the rearing period, higher body weight gain $(P<0.05)$ was seen in groups T0, T2, T3, and T4 compared to a positive control (T1), while significant differences $(P>0.05)$ between the negative control (T0; normal density 10 birds $/ \mathrm{m}^{2}$ ) and $\mathrm{T} 2$, and between T3 and T4 were not observed. Several studies have reported that high cage density can interfere with chicken growth and feed efficiency (Lara and Rostagno 2013; Yin et al 2017). The data in this study showed that clove leaf extract could reduce the negative impact of raising broilers with high stocking density ( 16 birds $/ \mathrm{m}^{2}$ ) on the growth performance of broilers..

The results of previous studies have shown that stress due to high density reduces body weight gain and feed consumption (Dozier et al 2005), impairs intestinal function associated with impaired nutrient absorption, thus in severe cases increasing mortality (Imaeda, 2000; Shakeri et al 2014). The results of this study indicate that clove leaf extract can improve the performance in broilers raised at high stocking density. In foregoing research resulted if feeding broilers with herbal plants can inhibit pathogenic bacteria, improve health of intestinal, antioxidant status, digestive function and immunity of chickens and therefore improve growth performance of poultry (Murugesan et al 2015; Nobakht et al 2016).

Table 2 Production traits of broiler chicks fed treatment diets.

\begin{tabular}{|c|c|c|c|c|c|c|c|}
\hline \multirow{2}{*}{ Observation } & \multicolumn{5}{|c|}{ Treatment } & \multirow{2}{*}{ SE } & \multirow{2}{*}{$P$-value } \\
\hline & TO & $\mathrm{T} 1$ & $\mathrm{~T} 2$ & T3 & $\mathrm{T} 4$ & & \\
\hline Initial weight (g) & 129.37 & 129.64 & 129.25 & 130.89 & 129.77 & 1.17 & 0.21 \\
\hline Final Weight (g) & $1428.64^{b}$ & $1301.66^{\mathrm{a}}$ & $1430.28^{b}$ & $1490.75^{c}$ & $1495.11^{c}$ & 78.83 & $<0.01$ \\
\hline Weight gain (g) & $1299.27^{b}$ & $1172.02^{\mathrm{a}}$ & $1301.03^{b}$ & $1359.86^{c}$ & $1365.34^{c}$ & 82.39 & $<0.01$ \\
\hline Ration Consumption (g) & $2118.19^{b}$ & $1991.77^{a}$ & $2170.63^{c}$ & $2213.43^{d}$ & $2221.72^{d}$ & 88.05 & $<0.01$ \\
\hline Ration Conversion & $1.63^{a}$ & $1.70^{\mathrm{b}}$ & $1.67^{\mathrm{ab}}$ & $1.63^{b}$ & $1.63^{\mathrm{b}}$ & 0.06 & 0.04 \\
\hline
\end{tabular}

There have been no studies to date that explain how clove leaf extract affects body weight increase in broilers raised at high stocking density. The effectiveness of clove leaf extract, on the other hand, is most likely due to the synergistic impact of numerous phytochemicals found in clove leaves (Adu et al 2020), which can improve chickens' physiological conditions. The latter situation enhances feed consumption and efficiency to increase broiler chicken growth performance. Due to their potential to scavenge free radicals and maintain intestinal mucosal integrity, phytochemicals like flavonoids, phenols, and saponins have enhanced higher growth rates and feed efficiency in broilers (Oloruntola et al 2019). According to a previous study, clove leaves also have antibacterial, antiparasitic, antifungal, anticoccidiotic, and hepatoprotective effects (Bhowmik et al 2012). These qualities can help broiler chickens grow faster by stimulating the growth of helpful bacteria, inactivating pathogenic bacteria, and facilitating nutrient metabolism and absorption in the digestive tract. Broiler chickens fed with clove leaf extract had a higher feed conversion rate than the positive control group (T1), indicating greater feed use. According to current studies, using phytogenic plants in broiler feed can improve intestinal digestibility, boosting broiler chicken growth (Sapsuha et al 2021).

Clove leaf extract given to broilers maintained at high stocking density resulted in higher feed consumption $(P<$ 0.05 ) during raising, leading to increased body weight gain. Essential oil-producing plants have improved feed flavor and delicacy and increased feed consumption and weight gain. (Sugiharto 2016). Essential oils found in clove leaves include terpene hydrocarbons (sabinene and pinene), myrcene, phellandrene, camphene, limonene, terpinene, myrcene, pcymene, and other terpene derivatives (Mahrous et al 2017; Al-Mufarrej et al 2019). 
The administration of clove leaf extract in broiler chickens raised at high stocking density significantly $(P<0.05)$ decreased the $\mathrm{pH}$ of the ileum and cecum but had no significant influence $(P>0.05)$ on the $\mathrm{pH}$ of the duodenum and jejunum, according to the results (Table 3 ). The decrease in intestinal $\mathrm{pH}$ caused by the administration of clove leaf extract in this study, especially in the ileum and cecum, was similar to the findings of Jamroz et al (2003) and Ferdous et al (2019). They found that the administration of plant extracts in the feed reduced the intestinal $\mathrm{pH}$ of broiler chickens significantly. The administration of clove leaf extract lowers the $\mathrm{pH}$ in the ileum and cecum, linked to an increase in the $L A B$ population in the ileum and cecum (Table 3 ). This occurs because $L A B$ can utilize glucose or simple sugars to grow and produce lactic acid. Lactic acid is one of the components of organic acids that play a role in lowering $\mathrm{pH}$ (Sanlibaba and Akmak 2016; Ngasotter et al 2020). The administration of clove leaf extract lowers the $\mathrm{pH}$ in the ileum and cecum, reducing the amount of harmful bacteria in the intestine while enhancing food digestibility. High acidity inhibits the growth of pathogenic bacteria, making the intestines healthier (Song et al 2014).

Table $3 \mathrm{pH}$ and bacterial population of broiler chickens fed treatment diets.

\begin{tabular}{|c|c|c|c|c|c|c|c|}
\hline \multirow{2}{*}{ Observation } & \multicolumn{5}{|c|}{ Treatment } & \multirow{2}{*}{ SE } & \multirow{2}{*}{$P$-value } \\
\hline & T0 & $\mathrm{T} 1$ & $\mathrm{~T} 2$ & T3 & $\mathrm{T} 4$ & & \\
\hline \multicolumn{8}{|l|}{$\mathrm{pH}$} \\
\hline Dedenum & 6.39 & 6.54 & 6.44 & 6.21 & 6.27 & 0.32 & 0.41 \\
\hline Jejenum & 5.91 & 5.88 & 5.84 & 5.68 & 5.57 & 0.48 & 0.72 \\
\hline Ileum & $5.88^{b}$ & $6.13^{a}$ & $5.50^{\mathrm{bc}}$ & $5.20^{\mathrm{bc}}$ & $4.73^{c}$ & 0.76 & $<0.01$ \\
\hline Cecum & $7.07^{b}$ & $7.68^{a}$ & $6.61^{c}$ & $6.36^{\mathrm{cd}}$ & $6.27^{d}$ & 0.64 & $<0.01$ \\
\hline \multicolumn{8}{|c|}{ Lactic Acid Bacteria } \\
\hline Ileum & $9.63^{b}$ & $8.29^{a}$ & $9.99^{b c}$ & $10.11^{b c}$ & $10.29^{c}$ & 0.86 & $<0.01$ \\
\hline Cecum & $9.67^{b}$ & $8.49^{a}$ & $10.22^{c}$ & $10.47^{c d}$ & $10.62^{d}$ & 0.82 & $<0.01$ \\
\hline \multicolumn{8}{|l|}{ Coliform } \\
\hline Ileum & $5.82^{b}$ & $7.36^{c}$ & $5.19^{a b}$ & $5.04^{\mathrm{ab}}$ & $4.58^{a}$ & 1.29 & $<0.01$ \\
\hline Cecum & $7.03^{b c}$ & $8.07^{c}$ & $6.64^{\mathrm{ab}}$ & $6.43^{\mathrm{ab}}$ & $5.56^{a}$ & 1.28 & $<0.01$ \\
\hline
\end{tabular}

a,b,cWithin the same row, the means with different superscript characters varied substantially $(P<0.05)$

The data in Table 3 shows that the administration of clove leaf extract in broiler chickens raised at high stocking density significantly $(P<0.05)$ increased lactic acid bacteria and significantly decreased $(P<0.05)$ coliform bacteria in the ileum and cecum. This study is in line with Jamroz et al. (2003) and Ferdous et al.'s (2019) studies which reported that supplementation of plant extracts as phytobiotics could increase the population of lactic acid bacteria and reduce $E$. Coli and total coliforms in the intestine.

Acidic conditions in the digestive tract, especially the ileum and cecum (Table 3), support the balance of the digestive tract microflora, where the population of lactic acid bacteria increases and the population of pathogenic bacteria decreases (Yadav and Jha 2019). Most infections thrive at a $\mathrm{pH}$ of around 7 or neutral. Beneficial microbes, on the other hand, thrive in an acidic $\mathrm{pH}(5.8-6.2)$ and compete with pathogenic bacteria, allowing for competitive exclusion (Rahmani et al 2005). Lactic acid bacteria create lactic acid, which helps broiler chickens' digestive tracts maintain an acidic $\mathrm{pH}$. In addition, acidic conditions in the digestive tract can increase the effectiveness of the process of absorption of nutrients by the walls of the digestive tract so that nutritional needs are fulfilled, health status is maintained, and productivity is increased (Mabelebe et al 2014; Krás et al 2013).

\section{Conclusions}

Clove leaf extract administration up to $1 \mathrm{ml} / \mathrm{kg}$ of feed can help broiler chickens raised at high stocking density enhance their performance and bacterial population.

\section{Conflict of Interest}

The authors declare that there is no conflict of interest.

\section{Funding}

Universitas Khairun Research and Community Service Institute (LPPM) provided funding assistance through the Graduate Competitive Research Program (PKUPT) for the 2021 fiscal year Contract No.: 020/PEN-PKUPT/PL/2021.

\section{References}

Adu OA, Gbore FA, Oloruntola OD, Falowo AB and Olarotimi OJ (2020) The effects of Myristica fragrans seed meal and Syzygium aromaticum leaf meal dietary supplementation on growth performance and oxidative status of broiler chicken. Bulletin of the National Research Centre 44:149.

Al-Mufarrej SI, Al-Baadani HH, Fazea EH (2019) Effect of level of inclusion of 
clove (Syzygium aromaticum) powder in the diet on growth and histological changes in the intestines and livers of broiler chickens. South African Journal Animal Science 49:166-175.

Bhowmik D, Kumar KPS, Yadav A, Srivastava S, Paswan S, Dutta SS (2012) Recent trends in Indian traditional herb Syzygium aromaticum and its health benefits. J Pharmacog Phytochem 1:1-23.

Dozier III W A, Thaxton J P, Branton S I, Morgan G W, Miles D M, Roush W B (2005) Stocking density effects on growth performance and processing yields of heavy broilers. Poultry Science 84:1332-8.

Ferdous MF, Arefin MS, Rahman MM, Ripon MMR, Rashid MH, Sultana MR, Hossain MT, Ahammad MU, Rafiq K (2019) Beneficial effects of probiotic and phytobiotic as growth promoter alternative to antibiotic for safe broiler production. J. Adv. Vet. Anim. Res. 6:409-415.

Guardia S, Konsak B, Combes S, Levenez F, Cauquil L, Guillot J F, MoreauVauzelle C, Lessire M, Juin H, Gabriel I (2011) Effects of stocking density on the growth performance and digestive microbiota of broiler chickens. Poultry Science 90:1878-1889.

Imaeda N (2000) Influence of the stocking density and rearing season on incidence of sudden death syndrome in broiler chickens. Poultry Sci 79:2014

Jamroz D, Orda J, Kamel C, Wiliczkiewicz A, Wertelecki T and Skorupinska J (2003) The influence of phytogenic extracts on performance, nutrient digestibility, carcass characteristics, and gut microbial status in broiler chickens. J. Anim. Feed Sci. 12:583-596.

Jeong SB, Kim YB, Jeong WL, Kim DH, Moon BH, Chang HH, Choi YH and Lee KW (2020) Role of dietary gamma-aminobutyric acid in broiler chickens raised under high stocking density. Animal Nutrition 6:293-304

Krás RV, Kessler AM, Ribeiro AML, Henn JD, Bockor L, Sbrissia AF (2013) Effect of dietary fibre, genetic strain and age on the digestive metabolism of broiler chickens. Brazilian J. of Poult. Sci. 15:83-90.

Lara LJ, Rostagno MH (2013) Impact of heat stress on poultry production. Animals 3:356-369.

Mabelebele M, Alabi OJ, Ng ambi JW, Norris D, Ginindza MM (2014) Comparison of gastrointestinal tracts and $\mathrm{pH}$ values of digestive organs of Ross 308 broiler and indigenous Venda chickens fed the same diet. Asian J of Anim. Vet. Adv. 9:71-76

Mahrous HB, El-far AH, Sadek KM, Abdel-Latif MA (2017) Effects of different levels of clove bud (Syzygium aromaticum) dietary supplementation on immunity, antioxidant status, and performance in broiler chickens. Alexandria J Vet Sci. 54:29-39.

Murugesan GR, Syed B, Haldar S, Pender C (2015) Phytogenic Feed Additives as an Alternative to Antibiotic Growth Promoters in Broiler Chickens. Frontiers Veterinary Science 2:21.

Ngasotter S, Waikhom D, Mukherjee S, Devi M S, Singh A S (2020) Diversity of lactic acid bacteria (LAB) in fermented fish products: a review. Int. J. Curr. Microbiol. App. Sci. 9:2238-2249.
Nobakht M, Darmani-Kuhi H, Mohiti-Asli M (2016) Effect of Zataria multiflora Boiss (thyme) extract on intestinal bacterial populations, meat cholesterol and carcass characteristics of broiler chickens fed diets with and without fat. Journal Animal Production Research 5:1-10.

Oloruntola OD, Ayodele SO, Adeyeye SA, Jimoh OA, Oloruntola DA, Omoniyi SI (2019) Pawpaw leaf and seed meals composite mix dietary supplementation: effects on broiler chicken's performance, caecum microflora, and blood analysis. Agroforestry Systems 94:555-564.

Rahmani HR, Speer W, Modirsanei M (2005) The effect of intestinal pH on broiler performance and immunity. Intl J. Poult Sci. 4:713-717.

Sanlibaba P, Çakmak G A (2016) Exopolysaccharides production by lactic acid bacteria. Appl. Micro. 2:1.

Sapsuha Y, Suprijatna E, Kismiati S, Sugiharto S (2021) The effect of nutmeg flesh (Myristica fragrans Houtt) extract on growth performance, internal organ and carcass of broiler chickens raised at high stocking density. Livestock Research for Rural Development 33:6.

Shakeri M, Zulkifli I, Soleimani AF, o'Reilly EL, Eckersall PD, Anna AA (2014) Response to dietary supplementation of L-glutamine and L-glutamate in broiler chickens reared at different stocking densities under hot, humid tropical conditions. Poultry Sci 93:2700-8.

Simitzis PE, Kalogeraki $E$, Goliomytis $M$, Charismiadou MA, Triantaphyllopoulos K, Ayoutanti A, Niforou K, Hager-Theodorides AL, Deligeorgis SG (2012) Impact of stocking density on broiler growth performance, meat characteristics, behavioural components and indicators of physiological and oxidative stress. Br. Poult. Sci. 53:721-730.

Song J, Xiao K, Ke YL, Jiao LF, Hu CH, Diao QY, Shi B, Zou XT (2014) Effect of a probiotic mixture on intestinal microflora, morphology, and barrier integrity of broilers subjected to heat stress. Poult. Sci. 93:581-588.

Sulieman AME, Elboshra IMO, Elkhalifa EAA (2007) Nutritive value of clove (Syzygium aromaticum) and detection of antimicrobial effect of its bud oil. Res J Microbiol 2:266-271.

Sugiharto S (2016) Role of nutraceuticals in gut health and growth performance of poultry. Journal of the Saudi Society of Agricultural Sciences 15:99-111.

Sugiharto S, Turini Y, Isroli I, Widiastuti E, Kusumanti E (2017) Dietary supplementation of probiotics in poultry exposed to heat stress - a review. Ann. Anim. Sci. 17:591-604.

Yadav S, Jha R (2019) Strategies to modulate the intestinal microbiota and their effects on nutrient utilization, performance, and health of poultry. Journal of Anim. Sci. Biotechnol. 10:2.

Yin LY, Wang ZY, Yang HM, Xu L, Zhang J, Xing H (2017) Effects of stocking density on growth performance, feather growth, intestinal development, and serum parameters of geese. Poultry Science 96:3163-3168. 